\title{
Self-Administration of Morphine, DAMGO, and DPDPE into the Ventral Tegmental Area of Rats
}

\author{
Darragh P. Devine and Roy A. Wise \\ Center for Studies in Behavioral Neurobiology, Department of Psychology, Concordia University, Montreal, Quebec, \\ Canada H3G $1 \mathrm{M} 8$
}

\begin{abstract}
Intracranial self-administration of $\mu$ - and $\delta$-opioid agonists was demonstrated in male Long-Evans rats. Independent groups were allowed to lever-press for ventral tegmental area (VTA) microinfusions of morphine, the selective $\mu$ agonist $\left[\mathrm{D}-\mathrm{Ala}{ }^{2}, \mathrm{~N}-\mathrm{Me}-\mathrm{Phe}^{4}-\mathrm{Gly}^{5}\right.$-ol]-enkephalin (DAMGO), the selective $\delta$-agonist [D-Pen $\left.{ }^{2}, \mathrm{D}-\mathrm{Pen}^{5}\right]$-enkephalin (DPDPE), or ineffective drug vehicle. Morphine, DAMGO, and DPDPE were each effective in establishing and maintaining lever-pressing habits. Lever-pressing responses were extinguished during a session when vehicle was substituted for drug, and reinstated when drug reinforcement was reestablished. Thus, it appears that VTA $\mu$ - and $\delta$-opioid receptors are each involved in reinforcement of opiate self-administration. The effective dose of DAMGO-both for establishing and for maintaining the lever-press habit-was 100 times lower than the effective doses for DPDPE and morphine, suggesting that the major contribution of VTA mechanisms to intravenous heroin self-administration involves an action on $\mu$-opioid receptors.
\end{abstract}

[Key words: $\mu$-opioid, $\delta$-opioid, ventral tegmental area, selfadministration, DAMGO, DPDPE]

Opiate actions in the ventral tegmental area (VTA) have been implicated in the habit-forming potential of opiates (for reviews, see Wise and Bozarth, 1982; Wise, 1989a). Rats will learn arbitrary operant bchaviors like lever-pressing (Bozarth and Wise, 1981 ) and nose-poking (Welzl et al., 1989) when those behaviors are reinforced with microinfusions of the mixed opioid agonist morphine directly into the VTA. Rats will also lever-press for VTA microinfusions of the mixed opioid agonist fentanyl (van Ree and de Weid, 1980).

Incentive motivational effects (see Wisc, 1989b) of opiates have also been related to actions in the VTA. VTA microinjections of morphine (Bozarth, 1987) or the methionine-enkephalin analog D-Ala ${ }^{2}-$ met $^{5}$-enkephalinamide (DALA; Phillips and LePiane, 1982; Phillips et al., 1983; Glimcher et al., 1984) each produce learned preferences for portions of the environ-

\footnotetext{
Received Fch. 12, 1993; revised Aug. 2. 1993; accepted Sept. 21, 1993.

This research was funded by grants from the Natural Sciences and Engineering Research Council of Canada and the National Institute on Drug Abuse of the United States (DA 11720 ). D.P.D. was supported by a scholarship from the Natural Sciences and Engineering Research Council of Canada. Important technical contributions were made by W. Mundl (design and construction of drug delivery systems and computer interface) and S. Cabilio (computer programming).

Correspondence should be addressed to Roy A. Wisc, Center for Studies in Behavioral Neurobiology, Concordia University, Room H-1013, 1455 de Maisonneuve Boulevard West, Montréal, Québec, Canada H3G 1 M8.

Copyright (c) 1994 Society for Neuroscience $0270-6474 / 94 / 141978-07 \$ 05.00 / 0$
}

ment associated with prior drug exposure. Conditioned place preferences are also observed after VTA microinjections of the enkephalinase inhibitor thiorphan (Glimcher et al., 1984). In addition, VTA microinjections of morphine lower the threshold for rewarding electrical stimulation of the lateral hypothalamus (Brockkamp et al., 1976; Jenck et al., 1987).

There are at least three major types of opioid receptors $(\mu, \delta$, and $\kappa$; Gilbert and Martin, 1976; Martin et al., 1976; Lord et al., 1977; Paterson et al., 1983) that could potentially be involved in the rewarding effects of opiates. The tritiated $\mu$ agonist ${ }^{3} \mathrm{H}$-DAMGO labels a dense population of $\mu$-opioid receptors in the VTA (Quirion ct al., 1983; Mansour et al.. 1987, 1988; Dilts and Kalivas, 1989; Spccialc et al., 1989), but data for the $\delta$ receptors have been less clear. The tritiated $\delta$ agonist ${ }^{3} \mathrm{H} \cdot[\mathrm{D}-$ Pen $^{2}$,D-Pen ${ }^{5}$-enkephalin ( ${ }^{3} \mathrm{H}$-DPDPE) has failed to label opioid receptors in the VTA (Mansour et al., 1987, 1988), but iodinated DPDPE (125I-DPIDPE; Dilts and Kalivas, 1990) and tritiated DSTBULET: ( ${ }^{3} \mathrm{H}$-DSTBULET; Delay-Goyet et al., 1990) each labels a sparse population of VTA $\delta$ receptors. The ineffectiveness of ${ }^{3} \mathrm{H}$-DPDPE may result from the fact that the VTA is rich in myelinated fibers, which may quench the relatively weak signal produced by ${ }^{3} \mathrm{H}-\mathrm{DPDPE}$ (sce Herkenham and Sokoloff, 1984; Kuhar and Unnerstall, 1985; Dawson et al., 1986; Dilts and Kalivas, 1990). Thus, it seems that there is actually a sparse population of $\delta$ receptors in the VTA. On the other hand, no significant $\kappa$ receptor binding has been found in the VTA (Mansour et al., 1987, 1988; Tempel and Zukin, 1987; Jomary et al. 1988), despite the use of an iodinated ligand (Jomary et al., 1988).

Conditioned place-preference studies have implicated actions involving $\mu$ and $\delta$ but not $\kappa$ receptors in the incentive motivational effects of opiates. Intracerebroventricular (Bals-Kubik et al., 1990a) or VTA (Bals-Kubik et al, 1990b) microinjections of [D-Ala ${ }^{2}, \mathrm{~N}-\mathrm{Me}$-Phe ${ }^{4}-\mathrm{Gly}^{5}$-ol]-enkephalin (DAMGO) each establish conditioned preferences for environments associated with prior drug exposure. Conditioned place preferences are also established by intracerebroventricular microinjections of DPDPE (Shippenherg et al., 1987; Bals-Kubik et al., 1990a).

VTA $k$ receptors may be uninvolved, or may mediate effects that are opposite to the rewarding effects produced by activation of $\mu$ and $\delta$ receptors. VTA injections of the $k$ agonist $U-50.488 \mathrm{H}$ fail to alter responding for rewarding electrical stimulation of the lateral hypothalamus (Jenck et al., 1987), but repeated systemic (Shippenberg and Herı, 1987; Shippenberg et al., 1988), intracerebroventricular (Bals-Kubik et al., 1989), or VTA (Bals. Kubik et al., 1990b) administration of either of the $\kappa$ agonists $\mathrm{U}-69,593$ or $\mathrm{U}-50,488 \mathrm{H}$ produces conditioned aversion to the drug-paired environment. 
Until now, the role of VTA $\mu$ and $\delta$ receptors in operant reinforcement of opiate self-administration has not been examined. The present experiments were designed to evaluate the involvements of these receptors in the habit-forming actions of opiates. In a preliminary investigation, rats were tested for intracranial self-administration of morphine to establish the experimental protocol and provide baseline data. Independent groups of rats were then tested for intracranial self-administration of DAMGO and DPDPE to evaluate the involvements of VTA $\mu$ and $\delta$ receptors in operant conditioning of opiate selfadministration.

\section{Materials and Methods}

\section{Animals and surgery}

Twenty-eight experimentally naive male Long-Evans rats (Charles River, Boston, MA) weighing 360-425 gm were individually housed with lights set on a reverse cycle (lights off at 8:00 A.M. lights on at 8:00 P.M.). Each rat was implanted under sodium pentobarbital anesthesia $(65 \mathrm{mg} / \mathrm{kg}$, i.p.) with a unilateral 22 -gauge guide cannula terminating $1.0 \mathrm{~mm}$ above the VTA $(3.6 \mathrm{~mm}$ posterior to bregma, $2.2 \mathrm{~mm}$ lateral to the midsagittal suture, and $7.6 \mathrm{~mm}$ ventral to dura). Surgery was performed with the incisor bar set $5 \mathrm{~mm}$ above the interaural line, and cannulas were angled toward the midline at $10^{\circ}$ from the vertical. (Measurements in the dorsal-ventral plane refer to distances along the track at $10^{\circ}$ from the vertical.) Stainless steel obturators ( 28 gauge) extending $1.1 \mathrm{~mm}$ beyond the tip of cach guide cannula were put in place at the time of surgery and removed for the duration of each test session.

\section{Drugs}

Morphine sulfate (mixed opioid agonist) was provided by the Canadian Department of Health and Welfare and was dissolved in Ringer's solution. The selective $\mu$-opioid agonist DAMGO (Handa et al., 1981; Goldstein and Naidu, 1989; Hruby and Gehrig, 1989) and the selective $\delta$-opioid agonist DPDPE (Mosberg et al., 1983, 1987; Akiyama et al., 1985; 1987; Hruby et al., 1991) were purchased from Sigma Chemical Co. DAMGO and DPDPE were dissolved in artificial extracellular fluid (aECF) that more closely approximates ion concentrations found in brain than does commercial Ringer's solution (Moghaddam and Bunney, 1989). This aECF was composed of a $2.0 \mathrm{~mm}$ Sorensen's phosphate buffer, containing $145 \mathrm{mM} \mathrm{Na}^{+}, 2.7 \mathrm{~mm} \mathrm{~K} \mathrm{~K}^{+}, 1.0 \mathrm{~mm} \mathrm{Mg} \mathrm{Mg}^{2+}, 1.2 \mathrm{~mm}$ $\mathrm{Ca}^{2+}, 150 \mathrm{~mm} \mathrm{Cl}^{-}$, and $0.2 \mathrm{~mm}$ ascorbate, at $\mathrm{pH} 7.4$.

\section{Apparatus}

Each rat was tested in a $27 \mathrm{~cm} \times 27 \mathrm{~cm} \times 27 \mathrm{~cm}$ operant chamber with a $5 \mathrm{~cm} \times 1.5 \mathrm{~cm}$ lever mounted in one wall, $6 \mathrm{~cm}$ above a grid floor. A wooden block was mounted under the lever to prevent the animals from inadvertently depressing the lever with their electrode cable while attending to the floor beneath the lever. A small white cue light was mounted in the wall of each chamber $9 \mathrm{~cm}$ above the lever. The operant chambers were contained in sound-attenuating boxes, which were dimly illuminated with red lights.

Drugs or vehicle solutions were delivered via electrolytic microinfusion transducers (EMITs; Plastics One, Roanoke, VA). These EMIT systems were similar to those previously described (Criswell, 1977; Bozarth and Wise, 1980; Bozarth, 1983). Briefly, each EMIT consisted of two platinum electrodes in a plastic reservoir, attached to a 28 -gauge injector cannula. These EMIT systems were connected via flexible lead wires and mercury commutators to a constant-current generator (Mundl, 1981). Contingent upon lever-presses, a $200 \mu \mathrm{A}$ current was delivered to the electrodes for $5 \mathrm{sec}$, generating gas from the aqueous solution contained in the reservoir. The gas produced over $5 \mathrm{sec}$ displaced a 120 $\mathrm{nl}$ infusion from the injector tip. Lever-presses that occurred during the drug infusions did not result in additional drug infusions.

Circling was detected by a rotometer that detected $360^{\circ}$ rotations of the electrode cable at the level of the commutator. Circling and leverpresses were monitored with a microprocessor.

\section{Intracranial self-administration procedure}

The rats were allowed to recover from surgery for at least $10 \mathrm{~d}$. Then, the rats were tested for intracranial self-administration of opioids in 4 hr sessions on each of 8 consecutive days. At the start of each of the first five sessions, each EMIT system was loaded with one of the drug solutions and the injector cannula was inserted through the guide cannula and anchored with its tip in the VTA. The rats were then allowed to lever-press for microinfusions into the VTA. The rats were not given any priming infusions, and lever-pressing was not shaped by successive approximations. During the sixth session (extinction session), each EMIT system contained vehicle rather than drug, and rats were tested as in the previous sessions. During the seventh and eighth sessions (reinstatement sessions), each EMIT system again contained the drug solution at the original concentration, and the rats were tested as in previous sessions. Circling was monitored throughout each session for the DAMGO, DPDPE, and aECF groups.

Preliminary investigation. Two groups of five rats each were tested. The rats in group 1 were tested for intracranial self-administration of morphine $\left(2.64 \times 10^{-3} \mathrm{M}\right.$, dissolved in Ringer's solution) and the rats in group 2 were tested for self-administration of the Ringer's vehicle alone. Each lever-press resulted in delivery of $3.16 \times 10^{-10} \mathrm{~mol}$ of morphine (or Ringer's solution) into the VTA.

After the eighth session, each rat was anesthetized with chloral hydrate and perfused with physiological saline followed by $10 \%$ formalin. Each brain was removed immediately, stored in formalin for 1 or more days, frozen, sliced in $40 \mu \mathrm{m}$ coronal sections, and stained with thionin for localization of VTA cannula tracks.

Intracranial self-administration of $\mu$ and $\delta$ agonists. Three groups of six rats each were tested. The rats in group 3 were tested for intracranial self-administration of DAMGO $\left(2.64 \times 10^{-9} \mathrm{M}\right.$, dissolved in aECF $)$. Each lever-press resulted in delivery of $3.16 \times 10^{-12} \mathrm{~mol}$ of DAMGO into the VTA. The rats in group 4 were tested for intracranial selfadministration of DPDPE $\left(2.64 \times 10^{-3} \mathrm{M}\right.$, dissolved in aECF). Each lever-press resulted in delivery of $3.16 \times 10^{-10}$ moles of DPDPE into the VTA. The rats in group 5 were tested for intracranial self-administration of aECF vehicle solution in each of the eight test sessions.

After the eighth session, each rat was anesthetized with chloral hydrate and perfused with a cold glyoxylic acid solution. Each brain was removed immediately, frozen on dry ice, and prepared for glyoxylic acid catecholamine histofluorescence, according to the method of Battenberg and Bloom (1975). The brains were sliced in $20 \mu \mathrm{m}$ coronal sections, and VTA cannula tracks were localized relative to the fluorescent dopamine cell bodies of the VTA.

\section{Statistics}

Group differences in daily rates of intracranial self-administration were evaluated using repeated-measures analyses of variance (ANOVAs). Significant effects were further analyzed with Tukey's tests, comparing values from the vehicle control and opioid groups during each of the daily sessions. Similarly, group differences in daily rates of circling (for DAMGO, DPDPE, and aECF groups) were analyzed using repeatedmeasures ANOVAs and Tukey's tests. The relationships between rates of intracranial self-administration and contraversive circling in the DAMGO and DPDPE groups were evaluated with simple logarithmic regression analyses.

The mean hourly rates of intracranial self-administration were calculated, based on the fourth and fifth days of testing. Group differences in hourly rates of intracranial self-administration were evaluated using repeated-measures ANOVAs. Significant effects were further analyzed with Tukey's tests. Similarly, group differences in mean hourly rates of intracranial self-administration during the extinction session were analyzed using repeated-measures ANOVAs and Tukey's tests.

\section{Results}

\section{Preliminary investigation}

The rats that were rewarded with VTA microinfusions of morphine lever-pressed infrequently at first, but then more regularly and rapidly over the course of the first and subsequent sessions. Stable elevated lever-pressing rates were established by the fourth and fifth sessions. In contrast, the rats whose lever-presses produced VTA microinfusions of Ringer's vehicle solution exhibited constant low daily rates of lever-pressing throughout the eight test sessions (Fig. 1). The daily rates of lever-pressing did not differ significantly between the morphine and Ringer's groups during session 6 (extinction session), but these rates rapidly 


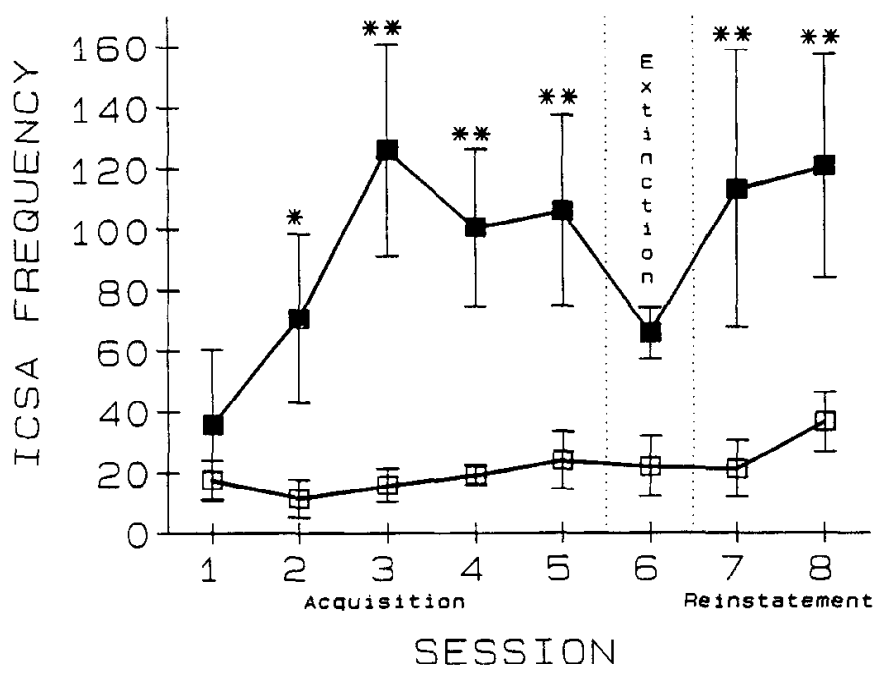

Figure 1. Daily rates of lever-pressing responses in the rats given access to VTA morphine ( $\square$ ) or Ringer's vehicle ( $\square$ ). The rats given access to morphine exhibited significantly higher daily lever-pressing frequencies than did the rats given access to Ringer's solution $\left[F_{(1.8)}=8.644, p<\right.$ $0.05]$. Values expressed are group means \pm SEM. Significant diffcrences in daily lever-pressing frequencies between the rats in the morphine group and the rats in the vehicle control group for each daily session (Tukey's tests) are depicted as follows: ${ }^{*}, p<0.05{ }^{* *}, p<0.01$.

increased again in the rats that were given response-contingent morphine during sessions seven and eight (reinstatement sessions).

The pattern of hourly lever-pressing rates for morphine and Ringer's (measured in the fourth and fifth sessions) is illustrated in Figure 2. The rats that were rewarded with VTA microinfusions of morphine responded rapidly in the early portion of these sessions and then stabilized at a lower but reliable rate of responding. In contrast, the rats infused with the Ringer's vehicle solution exhibited constant low rates of responding throughout these sessions (Fig. 2a). During the extinction session, the rats that had previously been rewarded with morphine responded rapidly at first but infrequently after the first hour (Fig. 2b). The rates of lever-pressing in these rats did not differ from the rates in the Ringer's control rats during the latter half of the extinction session (Fig. 2b).

$\Lambda \mathrm{ll}$ injector tips were located in the VTA. Placements of VTA injector tips are depicted in Figure 3. There were no apparent between-groups differences in the locations of VTA injector tracks.

\section{Intracranial self-administration of $\mu$ and $\delta$ agonists}

The rats that were rewarded with VTA microinfusions of DAMGO or DPDPE lever-pressed infrequently at first, but then more regularly and rapidly over the course of the first and subsequent sessions. Stable elevated lever-pressing rates were estahlished by the fourth and fifth sessions. This pattern of lever-pressing in the rats that received response-contingent DAMGO or DPDPE was similar to the pattern of responding in the rats that received morphine. In contrast, the rats in the aECF control group did not alter their daily response rates throughout the eight test sessions (Fig. 4). The daily rates of lever-pressing did not differ significantly between the DAMGO, DPDPE and aECF groups during the extinction session, but daily lever-pressing rates increased rapidly in both groups of rats that were rewarded with the opioids during the reinstatement sessions.
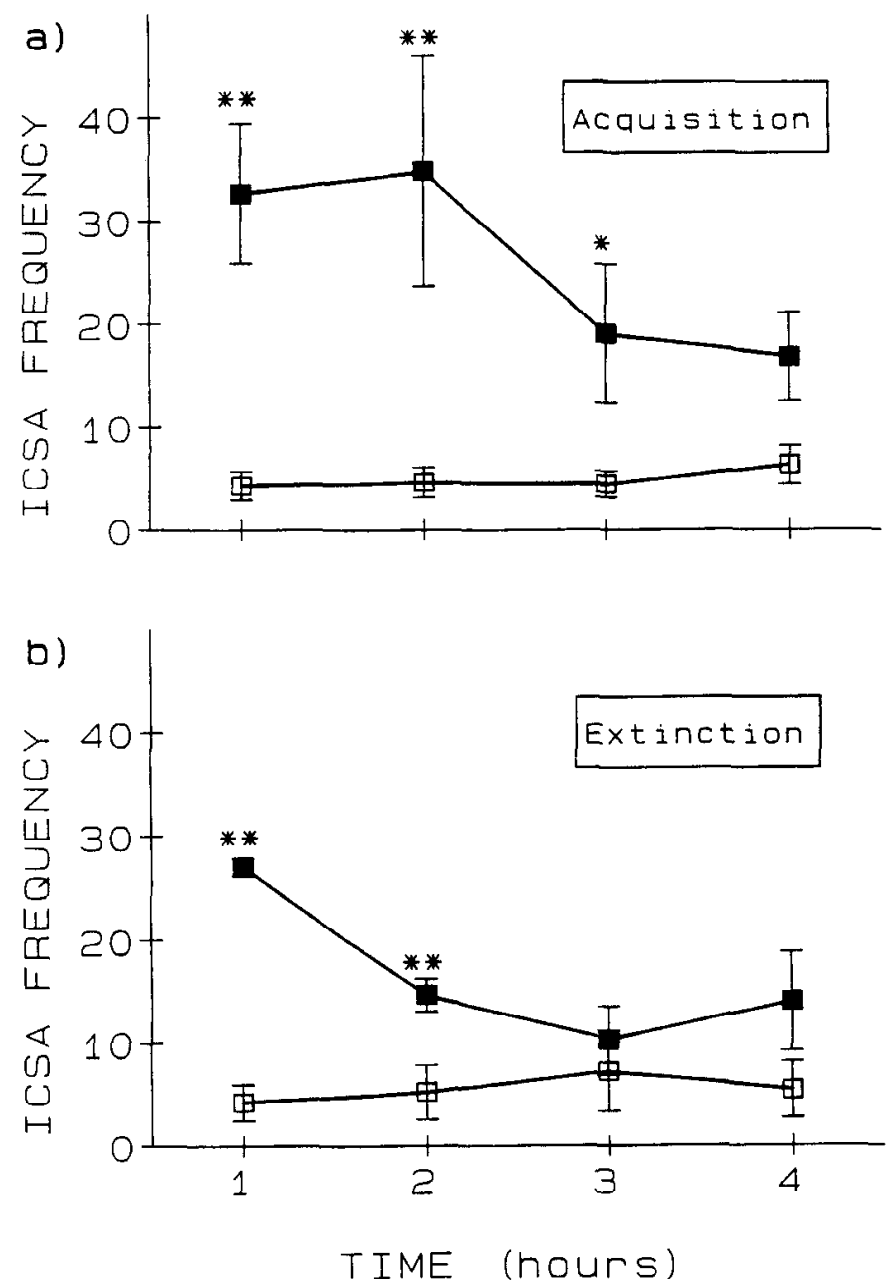

Figure 2. Hourly rates of lever-pressing responses in the rats given access to VTA morphine ( $\square$ ) or Ringer's vehicle ( $\square$ ). $a$, The rats given access to morphine exhibited significantly higher hourly rates of leverpressing, averaged across the fourth and fifth days of testing, than did the rats given access to Ringer's solution $\left[F_{(1,8)}=10.27, p<0.05\right] . b$, There was a significant group $\times$ trial interaction on the extinction day, indicating that the rats given access to morphine exhibited significantly higher hourly rates of lcver-pressing during the first $2 \mathrm{hr}$ of testing than did the rats given access to Ringer's solution $\left[F_{(3.24)}=7.903, p<0.01\right]$. Values expressed are group means \pm SEM. Significant differences in hourly lever-pressing frequencies between the rats in the morphine group and the rats in the vehicle control group for each hour (Tukey's tests) are depicted as follows: ${ }^{*}, p<0.05 ;{ }^{* *}, p<0.01$.

The pattern of hourly lever-pressing rates for DAMGO, DPDPE, and aECF (measured in the fourth and fifth sessions) is illustrated in Figure 5. The rats that were rewarded with VTA microinfusions of DAMGO or DPDPE each responded rapidly in the early portion of these sessions and then stabilized at lower but reliable rates of responding. Again, the pattern of responding in these rats was similar to the pattern of responding in the morphine-rewarded rats. In contrast, the rats infused with aECF exhibited constant low rates of responding throughout these sessions (Fig. 5a). During the extinction session, the rats that had previously been rewarded with DAMGO or DPDPE each responded rapidly at first but infrequently after the first hour (Fig. $5 b$ ).

The rats that self-administered DAMGO exhibited contraversive circling during all but the first of the five acquisition sessions. The rats that self-administered DPDPE also exhibited 


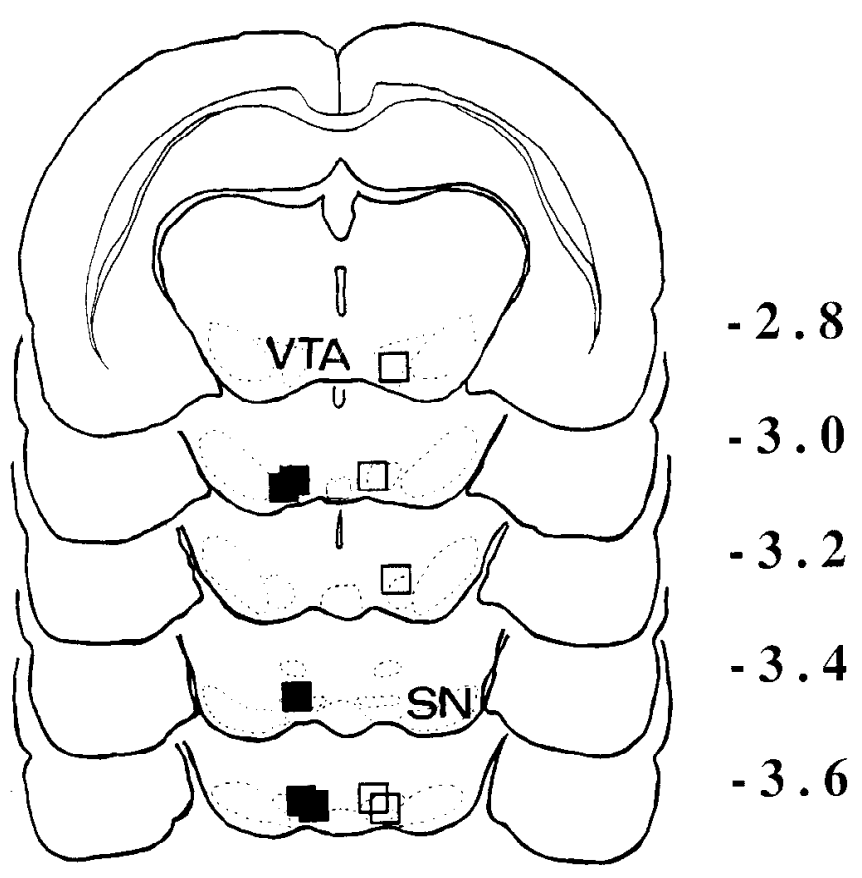

Figure 3. Histological reconstruction of areas where injector tips were identified in the ventral tegmentum in the rats given access to VTA morphine ( $\square$ ) or to Ringer's vehicle $(\square)$. Injector sites for the rats in the morphine and Ringer's groups are represented on opposing sides of the brain for the sake of clarity. All cannulas were implanted in the left hemisphere for these two groups. $S N$, substantia nigra; VTA, ventral tegmental area. Adapted from Pellegrino et al. (1979).

contraversive circling, but the rate of circling was significantly greater than that of the control group only during the first reinstatement session. Rates of circling did not differ significantly between the DAMGO, DPDPE, and aECF groups during the extinction session (Fig. 6). The daily rates of lever-pressing and circling were significantly correlated in the rats that sclf-administered DAMGO $\left[r=0.4051, F_{(1.46)}=9.031, p<0.01\right]$ and in the rats that self-administered DPDPE $\left[r=0.6572, F_{(1,16)}=\right.$ $34.98, p<0.01]$.

All injector tips were located within the boundaries of the dopamine-containing cell group of the VTA, as confirmed by fluorescence histochemistry. The approximate boundaries of the fluorescent cells and the placements of injector tips are depicted in Figure 7. There were no apparent between-groups differences in the locations of VTA injector tracks.

\section{Discussion}

The rats that were given response-contingent microinfusions of DAMGO or DPDPE into the VTA acquired a lever-pressing habit and maintained that habit whenever drug was accessible. They ceased lever-pressing when vehicle was substituted for the opioids, and rcinstated lever-pressing when the opioids were again available. This self-administration behavior in experimentally naive rats raises the possibility that VTA $\mu$ - and $\delta$-opioid receptors may each be involved in the rewarding and habitforming effects of opiates.

Within sessions, the rates of lever-pressing for DAMGO and for DPDPE was highest during the first hour of testing, and dropped off significantly during the following hours. This is consistent with the within-session pattern of responding that is seen with intravenous codeine (Downs and Woods, 1974) and intracranial morphine self-administration (Bozarth and Wise,

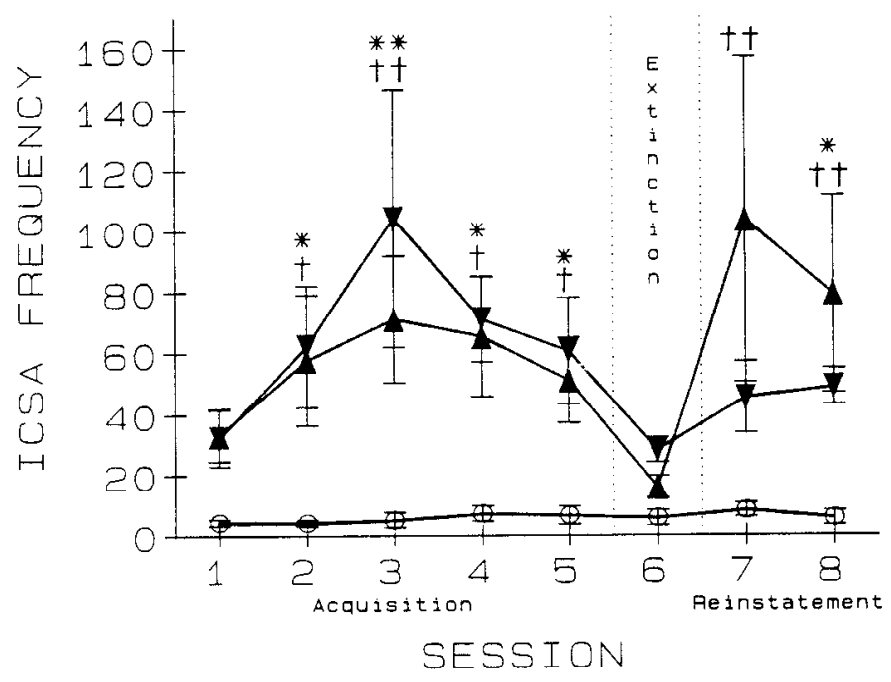

Figure 4. Daily rates of lever-pressing responses in the rats given access

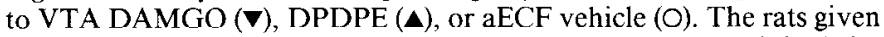
access to DAMGO and the rats given access to DPDPE exhibited significantly higher daily lever-pressing totals than did the rats given access to aECF $\left[F_{(2.15)}-10.09, p<0.01\right]$. Values expressed are group means \pm SEM. Significant differences in daily lever-pressing frequencies between the rats in the aECF group and the rats in the DAMGO and DPDPE groups for each daily session (Tukey's tests) are depicted as follows: ${ }^{*}, p<0.05 ;{ }^{* *}, p<0.01$ for DAMGO; $\uparrow, p<0.05 ; \dagger+p<$ 0.01 for DPDPE.

1981 ; present results). It has been suggested that this pattern of responding reflects the differential requirements of establishing and maintaining satiating concentrations of drug (Bozarth and Wise, 1981). The rats exhibit high rates of lever-pressing at the beginning of the session, until adequate tissue concentrations of drug are attained. Then, the rats exhibit lower rates of responding, as necessary to keep the tissue levels of drug at the requisite level.

The concentration of DPDPE $\left(2.64 \times 10^{-3} \mathrm{M}\right)$ that was required to initiate self-administration was 100 -fold higher than the effective concentration of DAMGO $\left(2.64 \times 10^{-5} \mathrm{M}\right.$; see Fig. 4). In pilot studies, rats failed to acquire self-administration of either of these drugs at lower concentrations than those reported herein (data not shown). Further, once stable responding was established, the rats lever-pressed for DAMGO and DPDPE at equivalent frequencies despite the 100-fold difference in concentrations (see Fig. 5a). Thus, 100 times more DPDPE than DAMGO was required to satisfy the rats within sessions. Similar differences in the potency of DAMGO and DPDPE have been reported in studies of conditioned place preference following intracerebroventricular microinjections (Bals-Kubik et al., 1990a), and locomotor activation and nucleus accumbens dopamine metabolism following VTA microinjections (Latimer et al., 1987).

The 100-fold difference in the concentrations of self-administered DAMGO and DPDPE raises the possibility that DPDPE exerted nonselective actions upon $\mu$-opioid receptors in the VTA. However, there is reason to believe that this is not the case in the dose range that was tested. VTA microinjections of DAMGO (Kalivas and Duffy, 1990; Spanagel et al., 1992; Devine et al., 1993) and DPDPE (Devine et al., 1993) each increase extracellular dopamine concentrations in the ventral striatum, and the effective doses of DPDPE are 100-fold higher than the approximately equieffective doses of DAMGO. Further, these 

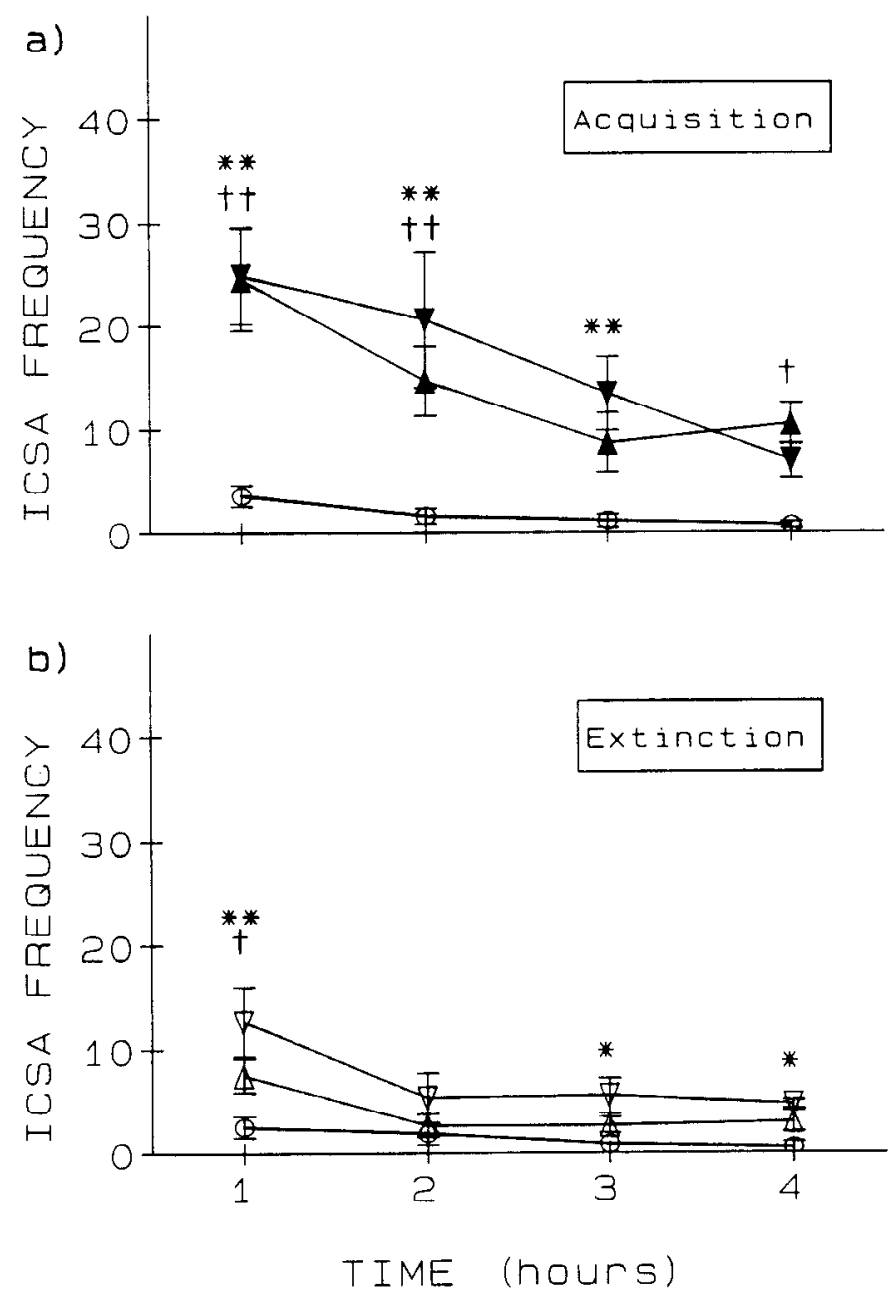

Figure 5. Hourly rates of lever-pressing responses in the rats given access to VTA DAMGO ( $\mathbf{v})$, DPDPE $(\Delta)$, or aECF vehicle $(0) . a$, The rats given access to DAMGO, and the rats given access to DPDPE exhibited significantly higher hourly rates of lever-pressing, averaged across the fourth and fifth days of testing, than did the rats given access to $\mathrm{aECF}\left[F_{(2,15)}=9.279, p<0.01\right] . b$, The rats previously given access to DAMGO, and the rats previously given access to DPDPE exhibited significantly higher hourly rates of lever-pressing during the first hour on the sixth day of testing than did the rats given access to aECF $\left[F_{(2.15)}\right.$ $=10.42, p<0.01]$. Values expressed are group means \pm SEM. Significant differences in hourly lever-pressing frequencies between the rats in the aECF group and the rats in the DAMGO and DPDPE groups for each hour (Tukey's tests) are depicted as follows: ${ }^{*}, p<0.05 ;{ }^{* *}, p<$ 0.01 for DAMGO; $\dagger, p<0.05 ; \dagger, p<0.01$ for DPDPE.

opioid-induced increases in dopamine concentrations are antagonized by the appropriate selective opioid antagonists (Devine et al., 1993). VTA microinjections of the $\mu$-selective antagonist D-Pen-Cys-Tyr-D-Trp-Orn-Thr-Pen-Thr-NH $\mathrm{NH}_{2}$ (CTOP) block the dopamine-modulating effects of VTA microinjections of DAMGO $\left(1.3 \times 10^{-11} \mathrm{~mol}\right)$, while failing to block the effects of DPDPE $\left(1.3 \times 10^{-9} \mathrm{~mol}\right)$. VTA microinjections of the $\delta$-selective antagonist naltrindole block the dopamine-modulating effects of VTA microinjections of DPDPE $\left(1.3 \times 10^{-9} \mathrm{~mol}\right)$, while failing to block the effects of DAMGO $\left(1.3 \times 10^{-11} \mathrm{~mol}\right)$. Thus, VTA injections of DAMGO and DPDPE each appeared to exert selective actions on VTA opioid receptors, despite the 100-fold difference in concentration, even at opioid doses that are four to five times higher than the doses that were self-administered in the present study.

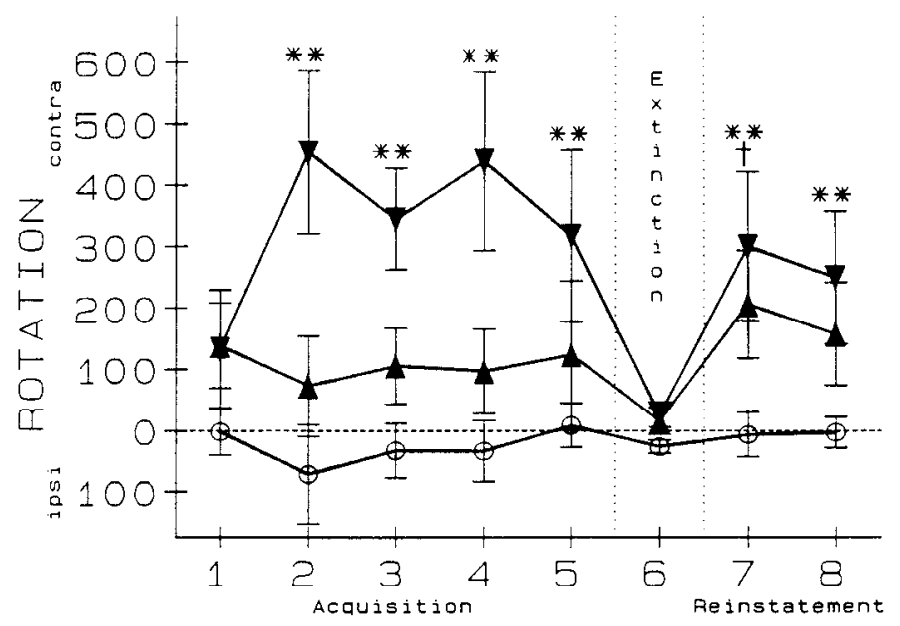

SESSION

Figure 6. Daily rates of circling in the rats given access to VTA DAMGO ( $\boldsymbol{\nabla})$, DPDPE (4), or aECF vehicle (O). There was a significant group $x$ trial interaction, indicating that the rats given access to DAMGO exhibited significantly higher daily rates of contralateral circling on six of the eight testing days than did the rats given access to aFCF, while the rats given access to DPDPE exhibited significantly elevated daily rates of contralateral circling only on the first reinstatement day $\left[F_{(14.105)}\right.$ $-2.198, p<0.05]$. Values expressed are group means \pm SEM. Significant differences in daily circling frequencies between the rats in the aECF group and the rats in the DAMGO and DPDPE groups for each daily session (Tukey's tests) are depicted as follows: ${ }^{* *}, p<0.01$ for DAMGO; $\dagger, p<0.05$ for DPDPE.

It has been proposed that the dopamine-modulating properties of opiates may account for or contribute to the rewarding properties of opiates in the VTA (Wise and Bozarth, 1987; Di Chiara and Imperato, 1988a,b). Thus, the fact that DAMGO is

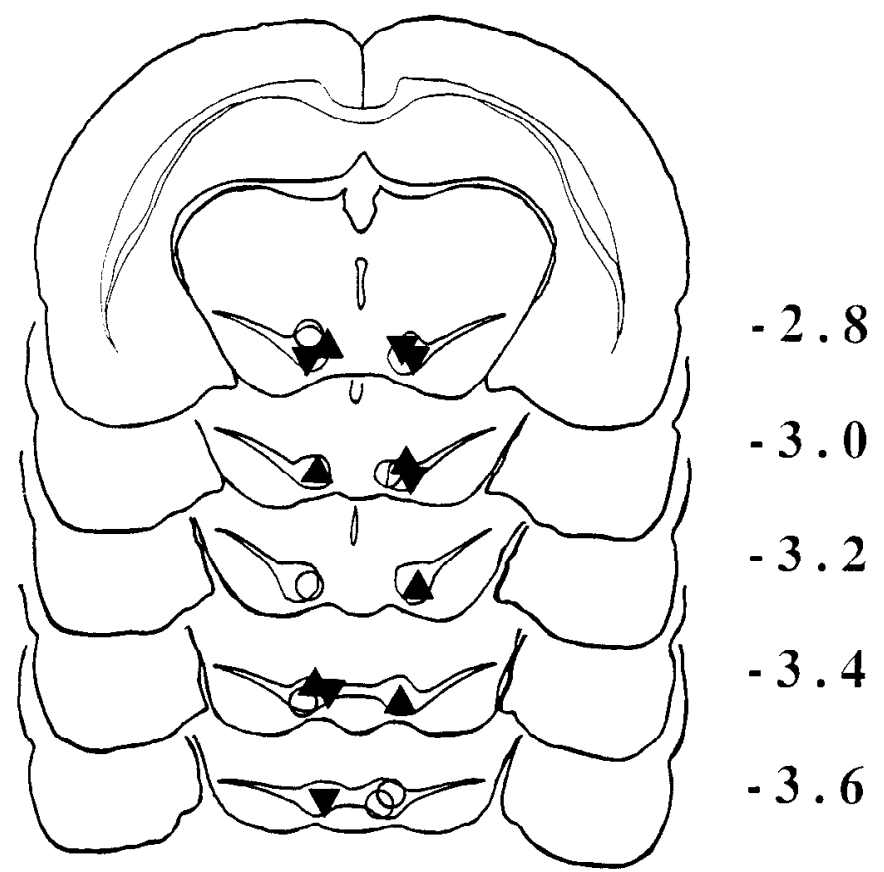

Figure 7. Histological reconstruction of sites where injector tips were located in the rats given access to VTA microinjections of DAMGO $(\nabla)$, DPDPE ( $\wedge$ ), or aECF vehicle $(O)$ in relation to the fluorescent cell body regions of the ventral tegmental area and substantia nigra pars compacta. 
100 times more potent in both the behavioral and neurochemical assays is particularly noteworthy.

The differences in potency between DAMGO and DPDPE could arise from differences in the densities of receptors that these two drugs act upon in the VTA. In accordance with Clark's (1933) theory of drug action, the association of a drug with its receptor is proportional both to the concentration of the drug, and to the number of free receptors at which the drug can act. In the present case, a high concentration of DPDPE may be required to promote association between the drug molecules and the relatively sparse $\delta$-receptor population in the VTA. The pharmacokinetic properties of DPDPE could also contribute to the differences in potency of DAMGO and DPDPE. DPDPE exhibits slow association with $\delta$-opioid receptors in brain tissue (Akiyama et al., 1985), and low rates of association between a drug and its receptor are associated with low drug potency (Ariëns, 1954; Paton, 1961). Thus, the potencies of DAMGO and DPDPE are commensurate with the densities of $\mu$ and $\delta$ receptors in the VTA, and with the known pharmacokinetic properties of DPDPE. Further, a comparison between the effective doses of morphine and DPDPE suggests that the effective dose of DPDPE was not inordinately high. In fact, the effective doses of morphine and DPDPE $\left(2.64 \times 10^{-3} \mathrm{M}\right)$ were equal.

The high potency of DAMGO after VTA microinjections, coupled with the high density of $\mu$-opioid receptors in the VTA, suggests that VTA $\mu$ receptors play an important role in the rewarding effects of opiates such as morphine and heroin. VTA $\delta$ receptors probably play a minor role in the rewarding effects of morphine and heroin administration. However, VTA $\mu$ - and $\delta$-opioid receptors may each contribute significantly to the actions of endogenous opioid peptides. The VTA is richly innervated by neurons that release enkephalin (Johnson et al., 1980), endogenous opioid peptides that act preferentially on $\delta$-opioid receptors (Lord et al., 1977). Thus, enkephalin in the VTA has a high affinity for the sparse population of VTA $\delta$ receptors, and a low to moderate affinity for the dense population of VT $\Lambda \mu$ receptors. Accordingly, it appears that enkephalin has the potential to act upon both $\mu$ - and $\delta$-opioid receptors in the VTA. Further, it appears that enkephalin actions in the VTA are involved in the neurobiology of opioid reward and in opioid modulation of dopaminergic activity. Conditioned place preferences (Glimcher et al., 1984) and increased locomotion (Kalivas and Richardson-Carlson, 1986; Daugé et al., 1992) have been produced by inhibition of enkephalinase activity in the VTA.

In the present study, the rats that self-administered DAMGO and DPDPE each exhibited contraversive circling, and the daily rates of self-administration and of contraversive circling were positively correlated in both the DAMGO and DPDPE groups. However, DPDPE self-administration produced substantially less contraversive circling (at a 100-fold higher concentration) than did DAMGO self-administration (see Fig. 6). In fact, the rate of circling from DPDPE self-administration did not differ significantly from the rates in aECF controls in six of the seven DPDPE-test days. The only session in which the rats that selfadministered DPDPE exhibited statistically significant rates of circling was the first reinstatement session. During this session, these rats self-administered more DPDPE than they had in previous sessions. It is thought that contraversive circling results from locomotor activation (Pycock and Marsden, 1978) that is associated with increased dopaminergic activity on the side of the intracranial injection (Andén et al., 1966; I Jngerstedt, 1971; Glick et al., 1976; Pycock and Marsden, 1978). Further, con- traversive circling (Jenck et al., 1988) and forward locomotion (Latimer et al., 1987; Calenco-Choukroun et al., 1991) have been observed after VTA administration of selective $\mu$ - and $\delta$-opioid agonists at higher doses than the doses that were selfadministered in the present study. Therefore, it appears that the weak locomotor effects of DPDPE in the present study result from dosage near the threshold for locomotor activation.

\section{References}

Akiyama K, Gee K, Mosberg HI, Hruby VJ, Yamamura HI (1985) Characterization of $\left[{ }^{3} \mathrm{H}\right][2-\mathrm{D}$-penicillamine, 5-D-penicillamine]-enkephalin binding to $\delta$ opiate receptors in the rat brain and neuroblastoma-glioma hybrid cell line (NG 108-15). Proc Natl Acad Sci USA 82:2543-2547.

Andén N-E, Dahlström A, Fuxe K, Larsson K (1966) Functional role of the nigro-striatal dopamine neurons. Acta Pharmacol Toxicol 24: 263-274.

Ariëns EJ (1954) Affinity and intrinsic activity in the theory of competitive inhibition. 1. Problems and theory. Arch Int Pharmacodyn 99:32-49.

Bals-Kubik R, Herz A, Shippenberg TS (1989) Evidence that the aversive effects of opioid antagonists and $\kappa$-agonists are centrally mediated. Psychopharmacology 98:203-206.

Bals-Kubik R, Shippenberg TS, Herz A (1990a) Involvement of central $\mu$ and $\delta$ opioid receptors in mediating the reinforcing effects of $\beta$-endorphin in the rat. Eur J Pharmacol 175:63-69.

Bals-Kubik R, Shippenberg TS, Herz. A (1990b) Neuroanatomical substrates mediating the motivational effects of opioids. In: New leads in opioid research. Proceedings of the International Narcotics Rescarch Conference (van Ree JM, Mulder AH, Wiegart VM, van Wimersma-Geidarus TB, eds), pp 11-12. Amsterdam: Exerpta Medica.

Battenberg ELF, Bloom FE (1975) A rapid, simple and more sensitive method for the demonstration of central catecholamine-containing neurons and axons by glyoxylic acid induced fluorescence. I. Specificity. Psychopharmacol Commun 1:3-13.

Bozarth MA (1983) Opiate reward mechanisms mapped by intracranial self-administration. In: The neurobiology of opiate reward processes (Smith JE, Lane JD, eds), pp 331-359. New York: Elsevier.

Bozarth MA (1987) Neuroanatomical boundaries of the reward-relevant opiate-receptor field in the ventral tegmental area as mapped by the conditioned place preference method in rats. Brain Res 414: 77-84.

Bozarth MA, Wise RA (1980) Electrolytic microinfusion transducer system: an alternative method of intracranial drug application. $J$ Neurosci Methods 2:273-275.

Bozarth MA, Wise RA (1981) Intracranial self-administration of morphine into the ventral tegmental area in rats. Life Sci 28:551-555.

Broekkamp CLE, Van den Boggard JH, Heynen HJ, Rops RH, Cools AR, Van Rossum JM (1976) Separation of inhibiting and stimulating effects of morphine on self-stimulation behavior by intracerebral microinjections. Eur J Pharmacol 36:443-446.

Calenco-Choukroun G, Daugé V, Gacel G, Féger J, Roques BP (1991) Opioid $\delta$ agonists and endogenous enkephalins induce different emotional reactivity than $\mu$ agonists after injection in the rat ventral tegmental area. Psychopharmacology 103:493-502.

Clark AJ (1933) Physico-chemical laws applicable to cell-drug reactions. In: The mode of action of drugs on cells, pp 42-59. Baltimore: Williams and Wilkins.

Criswell HE (1977) A simple chronic microinjection system for use with chemitrodes. Pharmacol Biochem Behav 6:237-238.

Daugé V, Kalivas PW, Duffy T, Roques BP (1992) Effect of inhibiting enkephalin catabolism in the VTA on motor activity and extracellular dopamine. Brain Res 599:209-214.

Dawson TM, Barone P, Sidhu A, Wamsley JK, Chase TN (1986) Quantitative autoradiographic localization of D-1 dopamine receptors in the rat brain: use of the iodinated ligand ( $\left.{ }^{125} \mathrm{I}\right) \mathrm{SCH} 23982$. Neurosci Lett 68:261-266.

Delay-Goyet P, Zajac J-M, Roques BP (1990) Improved quantitative autoradiography of rat brain $\delta$-opioid binding sites using $\left[{ }^{3} \mathrm{H}\right] D S T B U L E T$, a new highly potent and selective linear enkephalin analogue. Neurochem Int 16:341-368.

Devine DP, Leone P, Pocock D, Wise RA (1993) Differential involvement of ventral tegmental mu, delta and kappa opioid receptors in 
modulation of basal mesolimbic dopamine release: in vivo microdialysis studies. J Pharmacol Exp Ther 266:1236-1246.

Di Chiara G, Imperato A (1988a) Opposite effects of mu and kappa opiate agonists on dopamine release in the nuclcus accumbens and in the dorsal caudate of freely moving rats. J Pharmacol Exp Ther 244:1067-1080.

Di Chiara G, Imperato A (1988b) Drugs abused by humans preferentially increase synaptic dopamine concentrations in the mesolimbic system of freely moving rats. Proc Natl Acad Sci USA 85:5274-5278.

Dilts RP, Kalivas PW (1989) Autoradiographic localization of $\mu$-opioid and neurotensin receptors within the mesolimbic dopamine system. Brain Res 488:311-327.

Dilts RP, Kalivas PW (1990) Autoradiographic localization of delta opioid receptors within the mesocorticolimbic dopamine system using radioiodinated [2-D-penicillamine, 5-D-penicillamine]enkephalin (125 I-DPDPE). Synapse 6:121-132.

Downs DA, Woods JH (1974) Codeine- and cocaine-reinforced responding in rhesus monkeys: effects of dose on response rates under a tixed-ratio schedule. J Pharmacol Exp Ther 191:179-188.

Gilbert PE, Martin WR (1976) The effects of morphine- and nalorphine-like drugs in the nondependent, morphine-dependent and $\mathrm{cy}-$ clazocine-dependent chronic spinal dog. J Pharmacol Exp Ther 198: $66-82$.

Glick SD, Jerussi TP, Fleisher LN (1976) Turning in circles: the neuropharmacology of rotation. Life Sci 18:889-896.

Glimcher PG, Giovino AA, Margolin DH, Hoebel BG (1984) Endogenous opiate reward induced by an enkephalinase inhibitor, thiorphan, injected into the ventral midbrain. Behav Neurosci 98:262268.

Goldstein A, Naidu A (1989) Multiple opioid receptors: ligand selectivity profiles and binding site signatures. Mol Pharmacol 36:265272.

Handa BK, Lane AC, Lord JAH, Morgan BA, Rance MJ, Smith CFC (1981) Analogues of $\beta$ - $\mathrm{LPH}_{41}$ possessing selective agonist activity at $\mu$-opiate receptors. Eur J Pharmacol 70:531-540.

Herkenham M, Sokoloff L (1984) Quantitative receptor autoradiography: tissue defatting eliminates differential self-absorption of tritium radiation in gray and white matter of brain. Brain Res 321:363368.

Hruby VJ, Gehrig CA (1989) Recent developments in the design of receptor specific opioid peptides. Med Res Rev 9:343-401.

Hruby VJ, Toth G, Gehrig CA, Kao L-F, Knapp R, Lui GK, Yamamura HI, Kramer TH, Davis P, Burks TF (1991) Topographically designed analogues of [D-Pen,D-Pen $\left.{ }^{5}\right]$ enkephalin. J Med Chem 34:18231830.

Jenck F, Quirion R, Wise RA (1987) Opioid receptor subtypes associated with ventral tegmental facilitation of lateral hypothalamic brain stimulation reward. Brain Res 423:34-38.

Jenck F. Bozarth MA. Wise RA (1988) Contraversive circling induced by ventral tegmental microinjections of moderate doses of morphine and [D-Pen ${ }^{2}$.D-Pen ${ }^{5}$ enkephalin. Brain Res 450:382-386.

Johnson RP, Sar M. Stumpf WE (1980) A topographic localization of enkephalin on the dopamine neurons of the rat substantia nigra and ventral tegmental area demonstrated by combined histofluorescenceimmunocytochemistry. Brain Res 194:566-571.

Jomary C, Gairin JE, Cros J, Meunier JC (1988) Autoradiographic localization of supraspinal $k$-opioid receptors with $\left[{ }^{125}\right]-\mathrm{Tyr}^{1}, \mathrm{D}-$ Pro ${ }^{10}$ dynorphin A-(1-11). Proc Natl Acad Sci USA 85:627-631.

Kalivas PW, Duffy P (1990) Effect of acute and daily neurotensin and enkephalin treatments on extracellular dopamine in the nucleus accumbens. J Neurosci 10:2940-2949.

Kalivas PW, Richardson-Carlson R (1986) Endogenous enkephalin modulation of dopaminergic neurons in the ventral tegmental area. Am J Physiol 251:R243-R249.

Kuhar MJ, Unnerstall JR (1985) Quantitative receptor mapping by autoradiography: some current technical problems. Trends Neurosci $8: 49-53$.

Latimer LG, Duffy P, Kalivas PW (1987) Mu opioid receptor involvement in enkephalin activation of dopamine neurons in the ventral tegmental area. J Pharmacol Exp Ther 241:328-337.

Lord JAH, Waterfield AA, Hughes J, Kosterlitz HW (1977) Endogcnous opioid peptides: multiple agonists and receptors. Nature 267 : 495-499.

Mansour A, Khachaturian H, Lewis ME, Akil H, Watson SJ (1987)
Autoradiographic differentiation of mu, delta, and kappa opioid reccptors in the rat forcbrain and midbrain. J Neurosci 7:2445-2464.

Mansour A, Kachaturian H, Lewis ME, Akil H, Watson SJ (1988) Anatomy of CNS opioid receptors. Trends Neurosci 11:306-314

Martin WR, Eades CG, Thompson JA, Huppler RE, Gilbert PE (1976) The effects of morphine- and nalorphine-like drugs in the nondependent and morphine-dependent chronic spinal dog. J Pharmacol Exp Ther 197:517-532.

Moghaddam B, Bunney BS (1989) Ionic composition of microdialysis perfusing solution alters the pharmacological responsiveness and basal outflow of striatal dopamine. J Neurochem 53:652-654.

Mosberg HI, Hurst R, Hruby VJ, Gee K, Yamamura HI, Galligan JJ, Burks TF (1983) Bis-penicillamine enkephalins possess highly improved specificity toward $\delta$ opioid receptors. Proc Natl Acad Sci USA 80:5871-5874.

Mosberg HI, Omnaas JR, Goldstcin A (1987) Structural rcquircments for $\delta$ opioid receptor binding. Mol Pharmacol 31:599-602.

Mundl WJ (1981) Constant-current source for an electrolytic microinfusion transducer system. J Ncurosci Methods 4:287-290.

Paterson SJ, Robson LE, Kosterlitz HW (1983) Classification of opioid receptors. Br Med Bull 39:31-36.

Paton WDM (1961) A theory of drug action based on the rate of drugreceptor combination. Proc R Soc Lond [Biol] 154:21-69.

Pellegrino LJ, Pellegrino AS, Cushman AJ (1979) A stereotaxic atlas of the rat brain. New York: Plenum.

Phillips AG, LePiane FG (1982) Reward produced by microinjection of $\left(\mathrm{D}-\mathrm{Ala}^{2}\right), \mathrm{Met}^{5}$-enkephalinamide into the ventral tegmental area. Behav Brain Res 5:225-229.

Phillips AG, LePianc FG, Fibiger HC (1983) Dopaminergic mediation of reward produced by direct injection of cnkephalin into the ventral tegmental area of the rat. Life Sci 33:2505-2511.

Pycock CJ, Marsden CD (1978) The rotating rodent, a two component system. Eur J Pharmacol 47:167-175.

Quirion R, Zajac JM, Morgat JL, Roques BP (1983) Autoradiographic distribution of $\mathrm{mu}$ and delta opiate receptors in rat brain using highly selectrve ligands. Life Sci 33[Suppl 1]:227-230.

Shippenberg TS, Herz A (1987) Place preference conditioning reveals the involvement of $\mathrm{D}_{1}$-dopamine receptors in the motivational properties of $\mu$ - and $\kappa$-opioid agonists. Brain Res 436:169-172.

Shippenberg TS, Bals-Kubik R, Her $z$ A (1987) Motivational properties of opioids: evidence that an activation of $\delta$-receptors mediates reinforcement processes. Brain Res 436:234-239.

Shippenberg TS, Emmett-Oglesby MW, Ayesta FJ, Herz A (1988) Tolerance and selective cross-tolerance to the motivational cffects of opioids. Psychopharmacology 96:110-115.

Spanagel R, Herz A, Shippenberg TS (1992) Opposing tonically active endogenous opioid systems modulate the mesolimbic dopaminergic pathway. Proc Natl Acad Sci USA 89:2046-2050.

Speciale SG, Sadeg M, German DC (1989) Mu opioid receptor autoradiography: relationship to midbrain dopaminergic neurons. Soc Neurosci Abstr 15:96.10.

Tempel A, Zukin RS (1987) Neuroanatomical patterns of the $\mu, \delta$, and $\kappa$ opioid receptors of rat brain as determined by quantitative in vitro autoradiography. Proc Natl Acad Sci USA 84:4308-4312.

Ingerstedt IT (1971) Striatal dopamine release after amphetamine or nerve degeneration revealed by rotational behaviour. Acta Physiol Scand [Suppl] 367:49-68.

van Ree JM, de Weid D (1980) Involvement of neurohypophyseal peptides in drug-mediated adaptive responses. Pharmacol Biochem Behav 13:257-263.

Welzl H, Kuhn G, Huston JP (1989) Self-administration of small amounts of morphine through glass micropipettes into the ventral tegmental area of the rat. Neuropharmacology 28:1017-1023.

Wise RA (1989a) Opiate reward: sites and substrates. Neurosci Bıobehav Rev 13:129-133.

Wise RA $(1989 \mathrm{~b})$ The brain and reward. In: The neuropharmacological basis of reward (Liebman JM, Cooper SJ, eds), pp 377-424. Oxford: Oxford UP.

Wise RA, Bozarth MA (1982) Action of drugs of abuse on brain reward systems: an update with specific attention to opiates. Pharmacol Biochem Behav 17:239-243.

Wise RA, Bozarth MA (1987) A psychomotor stimulant theory of addiction. Psychol Rev 94:469-492. 